\title{
Forming a Life-World of Post-Soviet Daily Reality in the Context of National Security Provision
}

\section{Elena Yuryevna Bazhenova ${ }^{1}$}

\author{
Sergey Alexandrovich Dyuzhikov²
}

Aues Mukhamedovich Kumykov ${ }^{3}$

\section{Eugenia Sergeevna Sagalaeva 4}

\author{
Anna Mikhailovna Shapovalova ${ }^{5}$ \\ ${ }^{1}$ Institute of Sociology and Regional Studies, Southern Federal University \\ ${ }^{2}$ Institute of Sociology and Regional Studies, Southern Federal University \\ ${ }^{3}$ Kabardino-Balkarian State University \\ 4 Institute of Law, North-Caucasus Federal University \\ 5 Institute of Sociology and Regional Studies, Southern Federal University \\ Correspondence: Anna Mikhailovna Shapovalova, 160 Pushkinskaya, Rostov-on-Don, 344005, Russian Federation
}

Doi:10.5901/mjss.2015.v6n5s4p412

\begin{abstract}
The analysis of post-Soviet daily life based on characteristics of a perceived everyday world norm is conducted in relation to the definition of the latter, which is used as a reference guide to quantify features which can be considered ordinary, daily life and an individual's activities therein. Post-Soviet daily routine was being formed to the background of the Soviet Union collapse and the emergence of a new social reality. Ideological circumstances played a prominent role in this process with many of the relevant commemorations related to the Soviet past occurring today at the periphery of the ideological system, whilst still being incorporated in a discursive manner. Today, whilst there are drastic changes in the reform processes, the inconsistent interaction of embedded culture with the established culture generates a rejection of social innovations. All of this is the basis of a threat to the national security of Russia because it raises numerous contradictions in the perceived expected norms of life in Russia when compared to those perceived occurring around the world. In this regard, to ensure national security, it seems necessary to study the specifics of every day's life patterns, expectations and the established norms of everyday life present in modern post-Soviet Russia.
\end{abstract}

Keywords: lifeworld, everyday routine, the post-Soviet period, ideology, national security

\section{Introduction}

The "daily routine" concept, when considered from the perspective of socio-philosophical analysis, is similar to the philosophical category of "being/existence". What unites them is that both of these concepts denote existence, or a presence in the world. However, the primary difference, as far as the concept of "being" is understood, is the distinction between the real and the ideal, while the concept of "daily routine" generally implies a real, physical existence in the world. The idea of existence, when considered in relation to the idea of "the daily life" of a person, is surely primary in relation to everything else.

Daily routine is by its very nature linked with all varieties of behavior, survival and progress strategies with people creating, adapting and conforming to in the environment of their given specific socio-political conditions, including the most extreme ones. In regard to the problem of national security, in the context of the deployment of daily life, local socioenvironmental conditions and world social construction seem very relevant, due to the environment of daily life social practices, which determine the stability of a society, being a direct embodiment of the given situation.

In general, daily routine includes: event and circumstances of public daily life, usually associated with small private events; adaptation by an individuals to event circumstances occurring in the external environment; living conditions of private, domestic existence, daily routine in the broadest sense; the emotional side related to events and phenomena, individuals' and different social groups' experience of everyday domestic events and circumstances. 


\section{Literature Review}

The researcher N. L. Pushkareva associates everyday life with the attempt to understand the space of human experience. Because of this, the question of the content of the "daily life" concept involves consideration of what human experience should be taken into account (Pushkareva).

As for the post-Soviet daily routine and private lives of individuals, a great heuristic value is given to the sociophenomenological concept of lifeworld, which illustrates the dialectics of social knowledge and objective reality.

The concept of lifeworld (Lebenswelt) originally appeared in the philosophical works of E. Husserl (1913), from where it was borrowed and re-represented in the works by A. Schütz. He defined lifeworld through the characteristics of really visual, really tested and the available world, in which space the whole life is practically played (Schütz, 2004).

E. Husserl's followers (in particular M. Heidegger and A. Schütz) preferred to speak not so much about the "Lebenswelt", but about "Alltag", "Alltäglichkeit" or "alltägliche Lebenswelt" (respectively, "everyday life", "daily routine" and "everyday lifeworld") (Husserl, 1913). A. Schütz, based on the concept of lebenswelt, developed specific procedures of social cognition, creating a specific sociological concept of interactionist quality. Poring over the study of interpretive action specifics, committed by a social subject at the micro-level of social reality, he logically came to discover a new problematic field of sociological research, identified later as "the sociology of everyday life" (Kozhevnikov, 2008).

However, Schütz tries to get rid of uncertainty and fluctuation in the understanding of everyday lifeworld and defines it as a natural and social environment, that each of us takes as a given, that is to say for granted. This is the world of "determined indetermination". These are the framework, within which we open opportunities and, at the same time, is the place of realization of the latter. Thus, in this specific definition, the casual lifeworld seemingly appears as a sphere of ordinary, daily life and an individual's activity; if to talk in the language of modern sociology, it is that microenvironment which influences the formation of human personality and all vital activity functions.

For B.V. Dubin "day-to-day" is treated as "the space of out-of-hierarchical and unachieving behavior", because, in his view, the social hierarchy is absent, the social competition is weakened or even excluded and the focus is on the relationship of reciprocity and trust, based on influence and authority—not on power (Dubin).

\section{Research Methodology}

A substantive methodological role for the author was played by statements and conclusions from the works of $P$. Bourdieu (1992), Z. Bauman, E. Giddens, U. Habermas, containing fundamental provisions on the individualization of the living world as a daily routine. This includes a phenomenological theory of lifeworld by E. Husserl (1913); procedural theory of everyday life by G. Gadamer; the system theory of things by J. Baudrillard (Kellner, 1994).

Some approaches to understanding everyday life reflect the evolution of social thought in the context of classical, neoclassical and post-non-classic paradigms.

In this regard, the author relies on the use of historical-genetic analysis, which permits the identification of conceptual and categorical structures and the subject area of study based on a comparison of research and theoretical approaches, united by the themes of a private life and its ideological components.

\section{Results and Discussion}

Lifeworld has the properties of both objective and subjective reality. On the one hand it is given to a person, regardless of their wishes and preferences. On the other, its nature is intentional, which implies that subjective factors play a significant role in it.

The lifeworld of every social subject is formed during, and as a result of "social construction", material for which is "the indefinite diversity" of the objective world realities, and which social knowledge is the primary tool. This construction is carried out in line with the particular cognitive "metha-program", which dissects away all other potential and existing possibilities to form a specific "living world", made real through its unique specifics.

In other words, the lifeworld may be defined as a part of or by the objective "external" world, "captured" by a social subject from the "indefinite diversity" of objective world reality through social knowledge.

The phenomenological concept of lifeworld gained its social connotations through the phased transmission of the conceptual core of the phenomenological studies from logical-philosophical contexts into practical ones. This process was reflected in the change of the research field name as well.

However, a person's everyday lifeworld, is understood through phenomenological sociology and his close environment as defined in Marxist sociology, which are totally different things, the similarity are only apparent here. The representatives of phenomenological sociology reduce the entire individual experience to the subject's cognitive activities, 
which is not considered scientific, but commonplace-empirical cognition. Hence the casual lifeworld is predominantly nothing more than a scope of phenomena of a person's everyday consciousness, which for the dialectic, materialistic philosophy is a secondary sphere, derived from public and personal life and its reflection.

What is the daily lifeworld? Schütz, as well as other representatives of phenomenological sociology, have no single clear wording for the everyday lifeworld concept, leaving a description which is extremely ambiguous and contradictory.

The most common meaning, given as the "specific sector of the universe", consisting of past and present experience and knowledge of everyday things and events and about things that have not been included in actual experience and relevant knowledge spheres yet, but which are potentially accessible through experience which can make them known or understood.

The world is characterized as being open within and without. "From the outside, Schütz writes, it is a part of a more general larger whole, i.e., the universe, that serves as ... the external horizon of my everyday life world".

Inside, however, it is opened in a "spatial" way-to all of the objects in the external universe, located outside the limits of my actual accessibility; in time-the past and future-in the sense that it existed before me and will exist after me. It is also open in the sense of "reality" stages: the world of work, imagination, dreams, etc. And finally, it is open towards society-in the sense that it implies the existence of the lifeworlds of my contemporaries and predecessors and of future generations of people and of everything that they have created or will create (Schütz, 1988).

The term "social construction" applies to the realities of human relationships and may be used, not in the literal, but in the figurative sense. In fact in the socio-cognitive dimension not the elements of the objective reality being constructed but a certain excess of meanings, is a sort of "contingency fund" of semantic relationships. The latter alters the human perception of the objective reality, but not actually itself-although, impacting through symbolic mechanisms on people's consciousness and behavior, it can indirectly affect the objective trajectory of social relations' development.

The isolation of theoretical approaches as a way of conceptualizing the post-Soviet daily routine as the lifeworld, is the result of rapid social transformations with a universal character.

The post-Soviet daily routine was being formed at the beginning of the Soviet Union collapse and the emergence of a new social reality. The ideological circumstances played a prominent role here. For example, in August 1996 the President of the Russian Federation, Mr. Boris N. Yeltsin, spoke about the necessity of a nationwide idea search (Deryabin).

In parallel with this, in 1990's Russian society certain processes of mass-culture formation were happening. With the fall of the authoritarian order, the processes of democratic renewal started. The 'sprouts' of a civil society were emerging, a State of law was forming and the formation of a multiparty political system was initiated.

Modern Russian society is still going through a stage of democratic transition. However, in addressing significant social problems, including those that directly affect the day-to-day existence of millions of people, the authorities do not always use democratic methods and procedures, involving lengthy and open discussions and harmonization all members of the political process with the pending issues (Baranov, 2008). All of this is having an impact on various aspects of everyday life.

Throughout the democratization process of public life, some negative trends associated with the process of mass culture and virtualizations manifested.

I. P. Polyakova stresses that now some informational and consumer realities begin to substitute real life. Symbolic intermediaries begin to dominate human relations when communication occurs between virtual images (Polyakova, 2011).

Scientists recorded an identity crisis, destruction of the social spiritual reproduction system and an ideological vacuum, associated largely with the lack of clear national ideology capable to consolidate the society into a spiritual communion.

An increasingly prominent role is being played by popular culture, which in its own outline of social genesis, constructs its own system of social and moral guidance.

Thus, in the life of contemporary Russian society, fundamental changes are happening related to the transformation of virtually all areas of life, idea and expectation.

In the course of profound changes taking place in the reform processes, a contradiction between innovations and established regulatory culture is inevitably increasing, which leads to conflict tendencies, exclusion and an inhibition of innovation, and a rejection of forward thinking by the broad social strata (Frolova, 2014).

Processes of post-industrial socio-cultural transformation of a society affect individual personal content restructuring as well.

The situation is worsened by the absence of a structured symbolic value code of modern culture. Value symbols of Russian culture are contradictory and eclectic because they adjoin the most diverse elements (Frolova \& Volkov, 2015). 
S. A. Korolyov drew attention to these circumstances when writing about the specifics of Russian post-Soviet daily routine, explained primarily by the fact that the character of this daily routine is associated with brittle, rapid changes in the established manifestations of each individuals' daily existence, when the line between everyday life and out-ofeveryday-routine turns into normality.

From this the qualitative parameters and content-semantic peculiarities of modern Russian daily routine overlap with many indicators of a bygone Soviet everyday life or turn out to be directly associated with it.

Describing the State of modern Russian society, L. D. Gudkov says that it remained Soviet, in fact. Thus, he concludes, all our Soviet fears periodically come alive along with Soviet instincts, skills of adaptation and survival that can be described in a few words: we have to become invisible, "grey", to crouch, not to protrude, to pretend "unpalatable", and then, maybe, everything will be fine.

The willingness to participate in public and political life is extremely low, and continues to decline. Only the inhabitant of some of the larger cities have expressed their readiness to participate in political events. The main task is to survive. There is no readiness for change. "All these are inbuilt into Soviet citizens: he learned to coexist with the repressive state at the expense of a reduction in his own requirements, if necessary, being engaged in a corrupt relationship with it to solve his private problems" (Gudkov, 2014).

In fact, in Russian society, archaic relationships are artificially imposed "from above" and include the restoration of the class system, as oligarchy and upper-class bureaucracy have already taken shape as private class groups.

Post-Soviet daily life as a lifeworld is affected by the restoration of the Imperial theme, accompanied by the resurgence of anti-western moods and the Great State idea. Thus, the ideology and practice of the ruling elite, that is, of those who are involved in political decisions, indicate that in the course of the social modernization of the Soviet past, its various manifestations is represented in virtually all spheres of society life.

However, the imperial nostalgia has never been a key factor in the domestic politics of Russia. In 2000, responding to the question: "What is better: to be a Great State, which frightens other countries, or a country with a high standard of living, albeit not one of the most powerful ones?"-The first option was chosen by about 40 percent of respondents, while the second was chosen by 60 percent (annual surveys conducted in 2003, 2004, 2005, 2006, 2007, 2010). In December 2013 , replying to a question posed by the Levada; "What does Russia need most? The consolidation of state power or state power being placed under the control of society? " 58 percent chose the second option and 26 per cent chose the first (Horns, 2014).

A survey conducted in the spring of 2014 by the "Novye Izvestiya" newspaper, showed that more than half of the respondents do not trust the federal television channels, while only one in seven people unequivocally believes the information provided by television, whereas one third of the respondents did not believe "a word" created by journalists.

According to some sociologists, society is gradually forming a sort of people who are well oriented in the flow of information and are able to distinguish truth from fiction. Most often the inhabitants of large cities do not trust the Federal television channels, i.e., well educated people (Vorontsova, 2014).

But the past does not let go so easily and many people live by the past, unwilling to accept the "difficult present". Therefore, the dominant social players and the considerable society masses are increasingly turning to previous experience and chose to rely on traditional culture, which is accompanied by partial displacement of newfound modernity elements from society, culture and everyday practices.

And so the State begins to privatize privacy again. If under the Soviet rule, according to A. R. Usmanova, "privacy was confiscated by the State, or, in many cases, sacrificed voluntarily in favor of a collective project", then today we can say that the loss of privacy that is occurring right before our eyes and with ourselves is, on the one hand, implemented by all in the same methods of "enforcement" but with modern trends (security cameras in stores, on the streets, webcams), but this "sacrifice" is made for the betterment of the community (Usmanova). This view of "privacy" confirms that the loss of privacy should not necessarily be interpreted as a loss in a negative sense.

G. P. Sidorova believes that any study requires certain methodological limitations concerning its depth. Synthesis of different perspectives shows that daily routine covers "everything": work, focuses on the outside world, desires, fantasies, doubts, people's reactions to factual private events; geographical and environmental conditions of life, existence, production processes, needs and technologies for their satisfaction, values and rules, marriage forms and family institutions; methods of common actions, social rules and prejudices, the process of their formation; living habitat, various rituals and customs associated with it and behavioral practices (Sidorova, 2011).

This should also include the perception of official culture by the masses, mentality and household social psychology, practical logic; things surrounding people and how people treat these things; bodily experience; games, wishes and dreams, the verbal language; home and homestead farming; political preferences, morality, public opinion, interpersonal relations, superstition, wisdom, practical knowledge; games, rumors, tips; ideals, stereotypes of 
consciousness, value orientations; mass consciousness patterns governing behavior in the consumer sphere mostly; common working standards, rules of relaxation and rest, parenting, family and lovingly-intimate relationships, everyday thinking logic with typical errors; reality (lifeworld) of people from different social strata, their behavior and emotional reaction to events; the combination of prevailing practices associated with tastes and the preferences of individuals (Sidorova, 2011).

"Lifeword" as a special conceptual modus of vital reality includes a variety of private models and a model of everyday life holds a leading position here.

As V. D. Leleko postulates, daily life is given directly to the individual as a natural environment and habitat, concerning which there is no doubt and which, as a rule, does not create any problems for the person (Leleko, 2002).

\section{Conclusion}

Accordingly, the analysis of post-Soviet daily life in relation to the characteristics of the lifeworld is based on the definition of the latter as the area of ordinary, daily life and an individual's activity.

Lifeworld as a conceptual modus of the vital reality includes a variety of private models. The model of daily life occupies an important position among them.

Identification of theoretical approaches as a way of conceptualizing the post-Soviet daily routine as the lifeworld is due to the rapid social transformations of a universal character. Ideological circumstances played a prominent role in this and many of the "restored" fragments of the Soviet past occur at the periphery of the ideological system today, being incorporated in various discursive practices.

Processes of post-industrial socio-cultural society transformation influence the personal adjustment of an individual', who are as linked to the post-Soviet daily life as they are to the world.

Thus, in the life of contemporary Russian society, fundamental changes are happening, concerning the transformation of virtually all areas of existence. In the course of profound changes taking place in the reforming processes, the contradiction between innovations and the established regulatory culture is inevitably increasing which leads to conflict, exclusion and rejection of innovation and modernization by the broader social strata. All this can be a threat to national security, if not to devote sufficient attention to the problem of constructing a peaceful life and not to underestimate the factor of socio-cultural everyday space deployment.

\section{Acknowledgements}

This research was financially supported by the internal grant from the Southern Federal University No. 213.01-072014/15ПЧВГ "Threats to the national security in the face of geopolitical competition and models of aggressive and hostile behavior of young people".

\section{References}

Baranov, N. A. (2008). Evolyutsiya sovremennoy demokratii: Politicheskiy opyt Rossiyi. Avtoreferat dissdokt.polit.nauk. SpB. Vorontsova, V. (2014). Ob'ektovnaya lozh'. Novyie izvestiya. 18 aprelya.

Gudkov, L. (2014). Rossiyskoye obtschestvo ostalos' po suti, sovetskim. Retrieved from http://www.levada,ru/20-03-2014/

Deryabin, A. A. (1998). "Russkiy project": Konstruirovanie natsional'noy istorii i identichnosti.

Dubin, B. V. Byt, bytobtschina, obydennost': Ideya i istoriya povsednevnosti v Rossiyi.

Kozhevnikov, S. B. (2008). Sotsium v strukturakh zhiznennogo mira: Metodologicheskiy instrumentariy issledovania. Sotsiologicheskiy zhurnal.

Leleko, V. D. (2002). Prostranstvo povsednevnosti v evropeiskoy culture. SpB: Sankt-Peterburgskiy gos.un-t kultury i iskusstv. Retrieved from http://rudocs.exdat.com/docs/

Polyakova, I. P. (2011). Povsednevnost' v sotsial'no-filosofskom kontekste: Teoretiko-metodologicheskiy analiz. Aphtoreferat, diss.. dokt.filosofsk.nauk. M.

Pushkaryova, N. L. "Istoriya povsednevnosti" kak napravleniye istoricheskikh issledovaniy. Retrieved from http://www.krugosvet.ru

Rogov, K. (2014). Kak rossiyan ubezhdali v neobkhodimosti iranizatsii rossiyi. Novaya gazeta.

Rubtsov A. V. (2014). Summa legitimnosti. Ideologiya kak mashina (pp. 38-39). Vestnik evropy.

Sidorova G. P. (2011). Sovetskaya khozyaistvennaya kultura povsednevnosti v massovoy khudozhestvennoy literature 1960-1980 tsennostniy aspekt. Ul'yanovsk : Ul'GTU.

Usmanova, A. R. (2015). Utrachennaya privatnost': "tekhnologii" deprivatsiyi v sovetskom I postsovetskom kontextakh. Retrieved from http://gender-rout.org/

Frolova, A. S. (2014). K opredeleniyu I kharakteristike ideologicheskogo prostranstva Rossiyi. Sotsial'no-gumanitarniye znaniya.

Tschyuts, A. (2004). Izbrannoye: Mir, svetyatschiysya smyslom. M.: ROSSPEN. 